\title{
Extensive Peculiar Cutaneous Form of Neurofibromatosis Type I as a New Mutation - a Case Report
}

\author{
Jagoda BALABAN ${ }^{1, *}$, Dragana POPOVIĆ ${ }^{1}$, Svetlana PAVLOVIĆ 2 \\ ${ }^{1}$ Clinic of Skin and Venereal Diseases, University Clinical Centre of the Republic of Srpska, B\&H \\ ${ }^{2}$ Department of Pathology, University Clinical Centre of the Republic of Srpska, B\&H \\ *Correspondence: Jagoda Balaban, E-mail: jagoda.balaban@yahoo.com \\ DE GRUYTER
}

UDK 616.5-006.38-056.7

\begin{abstract}
Neurofibromatosis-1 (NF1) is one of the most common hereditary multisystemic disorders. The disease manifests a variety of characteristic features that include: hyperpigmentary abnormalities of the skin (café-au-lait macules, freckles in the axillae, and iris Lisch nodules) and growth of benign peripheral nerve sheath tumors (neurofibromas) in the skin. Associated extracutaneous clinical features include: skeletal abnormalities, neurological, cardiovascular, endocrine and other malformations. NF1 is caused by mutation in the neurofibromatosis-1 gene, which codes for the protein neurofibromin. The inheritance of NF1 follows an autosomal dominant trait, although about $50 \%$ of patients present with new („de novo“) mutations, and represent the first member of their family. No difference in the severity of the disease can be found in patients with familial mutations versus those with new mutations. We present a 78-year-old female patient with an extreme cutaneous form of neurofibromatosis who reported no affected family member. Apart from skin problems, she had no major health issues in childhood and adolescence, but in recent decades she had frequent headaches, occasional abdominal pain, and vision and hearing impairment. About 10 to 14 days before admission, she developed a severe cough, shortness of breath, and chest and abdominal pain. On examination, the patient of short stature (hight: $152 \mathrm{~cm}$, weight: $49 \mathrm{~kg}$ ) presented with thousands of soft nodules dispersed over the whole body, except on extensor sides of thighs and lower legs; the nodules varied in color from skin-colored, livid erythematous, to brown-grey; the nodules on the abdomen were moist, partly bleeding from the base, and accompanied by an unpleasant odor. Her feet were also densely covered by dark purple lumps, with dystrophic changes of the toe nails that were thickened, frayed, and yellowish. The skeletal abnormalities included: short stature, severe osteoporosis and osteosclerosis of the head bone structure; degenerative arthropathc-spondylotic changes of the thoracolumbar spine segment with signs of diffuse skeletal hyperostosis; pronounced degenerative changes of the lumbar spine. CT scans of the head, chest and abdomen showed the following abnormalities: flattening of the paraventricular gyri and reduction of brain parenchyma with hypodensity of the white matter in terms of cortical atrophy; periventricular bilateral small post-ischemic microvascular brain lesions of varying chronicity; in the parenchyma of the upper left lung lobe the apical presence of small areas of pleural effusion with consequent subatelectic region; distended stomach and a small inner wall herniation; hypotrophic right kidney; atherosclerotic lesions of the abdominal aorta; low grade infrarenal kinking of the abdominal aorta. Pathohistological analysis of biopsy specimen taken from the nodule corresponded with cutaneous neurofibroma. Consultative examinations of various specialists pointed to the existence of the following comorbidities: obstructive respiratory syndrome and right lobe pneumonia that were treated by antibiotics, aminophylline and dexamethasone infusions; psycho-organic syndrome without focal neurological deficit; Lisch nodules in each eye, and senile cataract. Considering the age and medical presentation of the patient, no other treatment was considered. In conclusion, this is a sporadic case of cutaneous neurofibromatosis 1 in a 78-year-old female patient who presented with extremely severe cutaneous neurofibromas, making this case at least rather peculiar.
\end{abstract}

\section{Key words}

Neurofibromatosis 1; Neurofibromin 1; Café-au-Lait Spots; Iris Diseases; Melanosis; Neurofibroma; Skin Neoplasms; Case Reports; Comorbidity 
$\mathrm{N}_{\mathrm{s}}$ eufibromatoses (NFs) comprise several distinct genetic disorders that lead to the formation of tumors involving nerve tissue. The two main forms are NF1 and NF2, the first also known as von Recklinghausen disease with characteristic skin lesions, opposite to the second which does not present with cutaneous manifestations (1).

Neurofibromatosis 1 (NF1), or von Recklinghausen disease, is a multisystemic disorder that affects approximately 1 in 3.500 people (2). Althouh the earliest historical descriptions originate from the $13^{\text {th }}$ century, in 1882, Friederich von Recklinghausen published a landmark paper On the Multiple Fibromas of the Skin and Their Relationship to the Multiple Neuromas, describing this disease and pointing out that the skin tumors were derived from peripheral nerves (3). More recently, in 1956, Crowe, Schull and Neel published a milestone manuscript detailing the numerous manifestations of this disorder $(4,5)$. NF1 is caused by a heterozygous mutation in the NF1 gene located on chromosome 17 which encodes a protein named neurofibromin. The NF1 gene has one of the highest mutation rates among all other genes within the human genome. More than 500 different mutations in the NF1 gene have been identified. The mode of inheritance is autosomal dominant, with almost $100 \%$ penetrance by the age of 5 years (1). Familial occurrence is reported in about half of affected individuals, the rest are sporadic cases resulting from a high gene mutation rate which accounts for $50 \%$ of all cases (6). Since each affected individual and family has specific mutations, genetic screening is highly challenging (1). No difference in the severity of the disease can be found in patients with familial mutations versus those with new mutations. Major diagnostic criteria for NF1, established by the National Institutes of Health (NIH) are based on clinical findings and require 2 or more of the following criteria: 6 or more "cafe au lait macules" (CALMs) with diameter $>5 \mathrm{~mm}$ and $>15 \mathrm{~mm}$ in prepubertal and postpubertal patients, respectively; $\geq 2$ of any type of neurofibromas, or at least 1 plexiform neurofibroma; axillary or inguinal freckling; $\geq 2$ Lisch nodules on the iris; distinctive osseous lesion; an optic nerve glioma; first-degree relative with NF1. The hallmark features of the disorder are CALMs and neurofibromas. The disease is not only a neurocutaneous but also a multisystemic disorder, with multifaceted implications throughout nearly every organ system in the human body. The most common extracutaneous complications are related to skeletal abnormalities, ophthalmic, neurological, endocrine, vascular and cardiac disorders including tumors (7). The treatment of NF1 focuses on symptom management, as well as radio- and chemotherapy in case of malignant alterations. Other treatment options include lovastatin, rapamycin (or sirolimus), imatinib mesylate and even topical vitamin D3 analogues (8).

\section{Case report}

We present a 78-year-old female patient, resident of the Gerontology Centre in Banja Luka, who was referred to the Clinic of Skin and Venereal Diseases of the University Clinical Center of the Republic of Srpska, due to itching in the area of anterior abdominal wall, coughing, shortness of breath, chest and abdominal pain. On admission, the patient reported having skin tumors since childhood, whose number gradually increased, especially after 30 years of age, and they covered the skin of her entire body; due to learning difficulties, she could not read or write, and no other family member, including seven brothers and two sisters, who are all alive except one brother, had similar skin tumors. This information was confirmed by the head nurse and director of the Gerontology Center who are in contact with her family. Apart from skin lesions, she had no major health problems in childhood and youth, but in recent decades she had frequent headaches, occasional abdominal pain, and vision and hearing impairment. The patient also reported an elbow surgery on her left arm a few decades ago; she had no other health problems, and apart from analgesics, she was not taking other medications. Since no proper medical documentation was available, and she had a scar on her elbow, we assumed that she underwent surgical excision of one of the largest tumors. About 10 to 14 days before admission, she developed a severe cough, shortness of breath, and chest and abdominal pain.

\section{Physical examination}

On examination, the patient of short stature (height: $152 \mathrm{~cm}$, weight: $49 \mathrm{~kg}$ ) presented with thousands of soft nodules dispersed over the whole body, except 


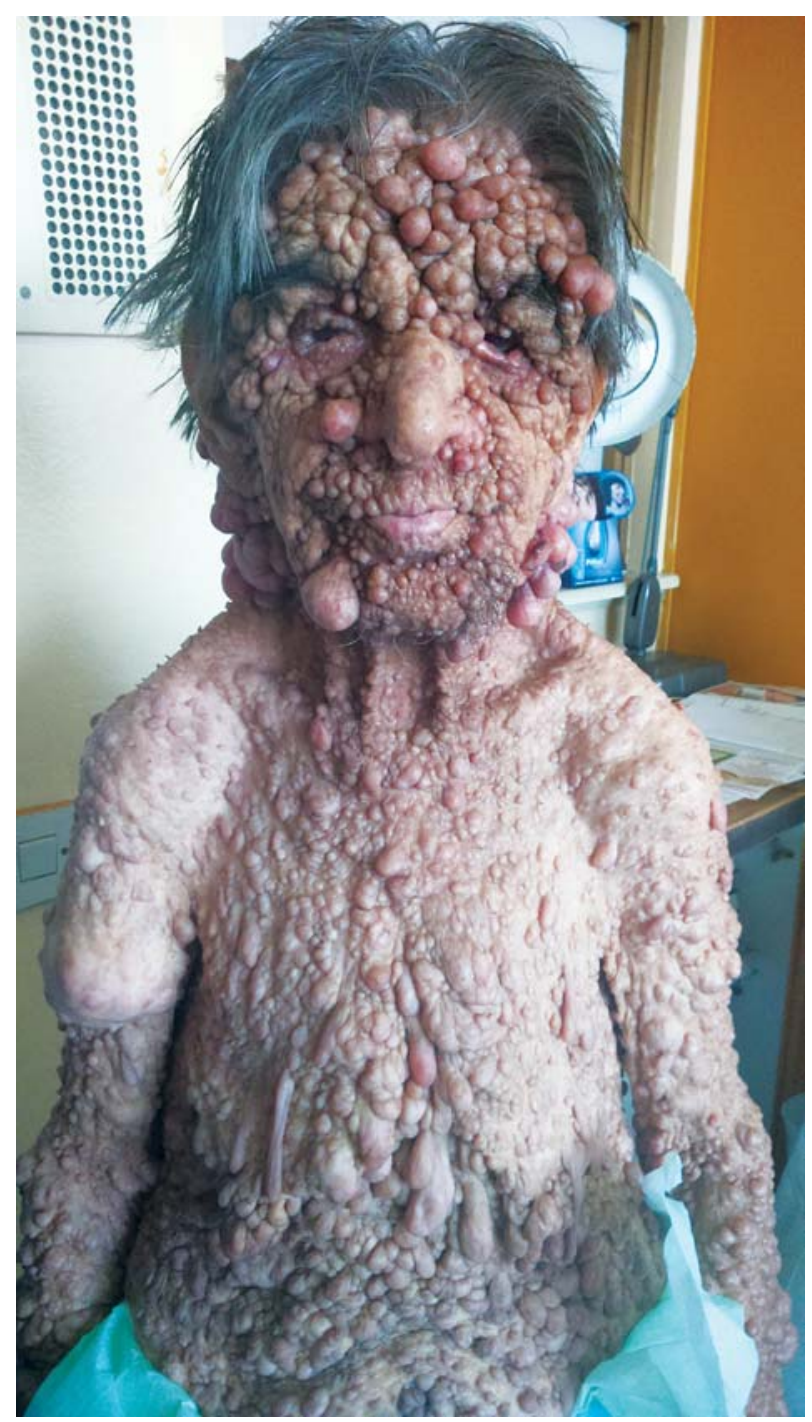

Figure 1. Numerous, densely distributed cutaneous neurofibromas on the face and on the chest, different in size, many connected to the skin by a stalk

on extensor sides of thighs and lower legs (Figures 1 - 3); the nodules varied in color from skin-colored, livid erythematous, to brown-grey; the nodules on the abdomen were moist, partly bleeding from the base, and accompanied by an unpleasant odor (Figure 4). The size of nodules ranged from $0.5 \mathrm{~cm}$ to $15 \mathrm{~cm}$ in diameter, many of which had elongated patellar base; some nodules were covered by comedones (Figure 5); nodules were most densely grouped in the occipital and abdominal region, and along the central part of the back forming clusters (Figure 6). The two largest, giant, baggy nodules were localized on the extensor

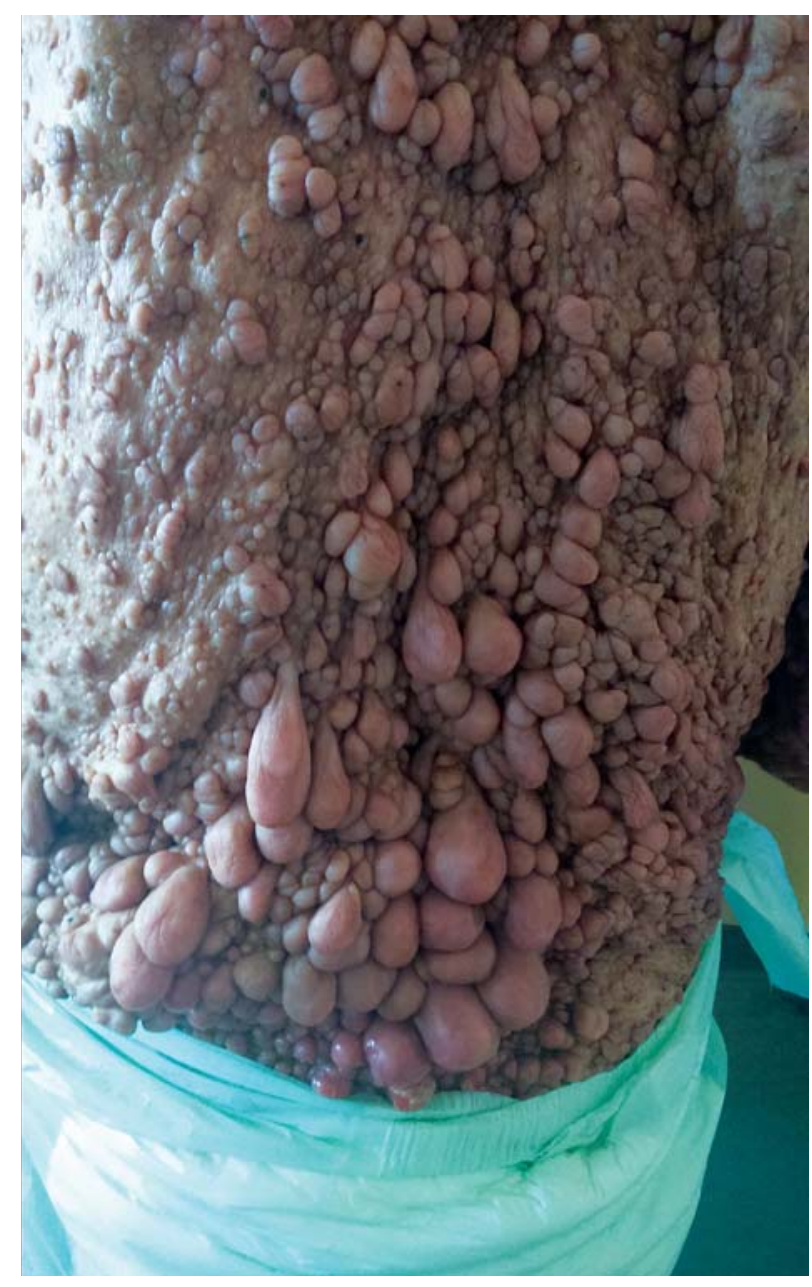

Figure 2. Densely distributed neurofibromas forming clusters in the lumbosacral region

aspects of the right upper arm and left leg (Figure 7). Four typical "café au lait" spots of different sizes were found on the trunk and lower extremities, as well as 4 - 5 smaller pale brown maculae (Figure 8). A large number of brownish spots were found in the inguinal region and on the inner sides of thighs (Figure 9). Her feet were also densely covered by dark purple lumps, with dystrophic changes of the toe nails that were thickened, frayed, and yellowish.

\section{Laboratory and other test results}

Erythrocyte sedimentation rate $65 \mathrm{~mm} / \mathrm{h}$, C-reactive protein $147.5 \mathrm{mg} / \mathrm{L}$ (reference level $<5.0 \mathrm{mg} / \mathrm{L}$ ), white blood cell count $9.2 \times 10^{9} / \mathrm{L}$ (reference range $3.4-9.3$ ) with neutrophils $80.8 \%$ (reference range $40-77 \%$ ), lymphocytes $11.7 \%$ (reference range $16-44$ ); red 


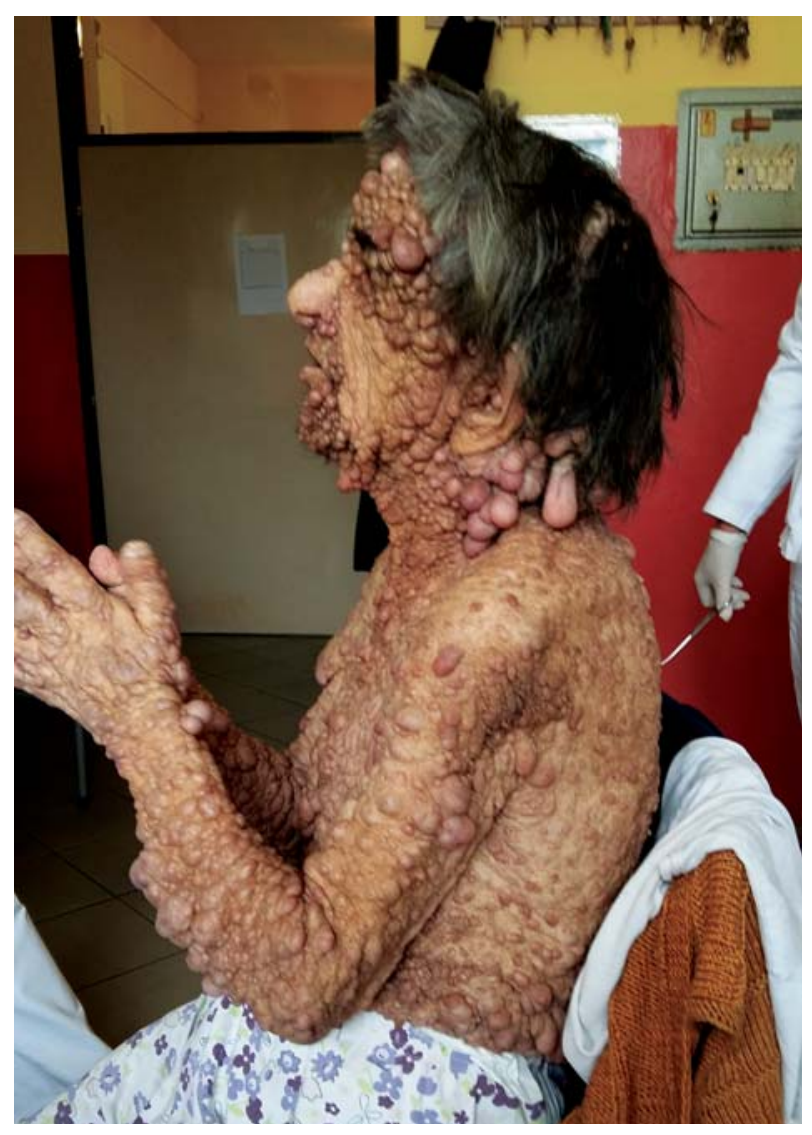

Figure 3. Neurofibromas on the upper body and arms blood cell count $4.8 \times 10^{12} / \mathrm{L}$ (reference range $3.8-5.1$ $\mathrm{x} 10^{12 /} \mathrm{L}$ ), hemoglobin $114 \mathrm{~g} / \mathrm{L}$ (reference range 119 157), platelets $452 \times 10^{\%} / \mathrm{L}$ (reference range $158-424$ $10 \% / \mathrm{L}$ ), urea $9.2 \mathrm{mmol} / \mathrm{L}$ (reference range $2.8-7.2$ $\mathrm{mmol} / \mathrm{L}$ ), creatinine $125 \mu \mathrm{mol} / \mathrm{L}$ (reference range $44-80 \mu \mathrm{mol} / \mathrm{L}$ ), alanine aminotransferase $53 \mathrm{U} / \mathrm{L}$ (reference value $<40 \mathrm{~J} / \mathrm{L}$ ), aspartate aminotransferase $110 \mathrm{U} / \mathrm{L}$ (reference value $<37 \mathrm{~J} / \mathrm{L}$ ). The following serum levels of tumor markers were estimated (ECLIA, Cobas E601): CA 125 carbohydrate antigen 16.3 $\mathrm{KU} / \mathrm{L}$ (reference value < $5 \mathrm{U} / \mathrm{L}$ ). CA 19-9 carbohydrate antigen $30.2 \mathrm{KU} / \mathrm{L}$ (reference value $<27.0$ ), CA $72-4$ (s) serum cancer antigen $2.2 \mathrm{KU} / \mathrm{L}$ (reference value < $6.9 \mathrm{kU} / \mathrm{L}$ ), carcinoembryonic antigens CEA $6.4 \mu \mathrm{g} / \mathrm{L}$ (reference value $<5.0 \mu \mathrm{g} / \mathrm{L}$ ), serum neuron-specific enolase antigen NSE (s) $7.2 \mu \mathrm{g} / \mathrm{L}$ (reference value < $16.3 \mu \mathrm{g} / \mathrm{L}$ ). Urinalysis showed $2+$ protein.

Microbiology testing: Staphylococcus aureus and Viridans streptococci were isolated from the skin specimens collected from the surface of the inflammed nodules.

Microbiology testing of nasal swabs: Proteus mirabilis was isolated. mal flora.

Microbiology testing of throat swabs: nor-

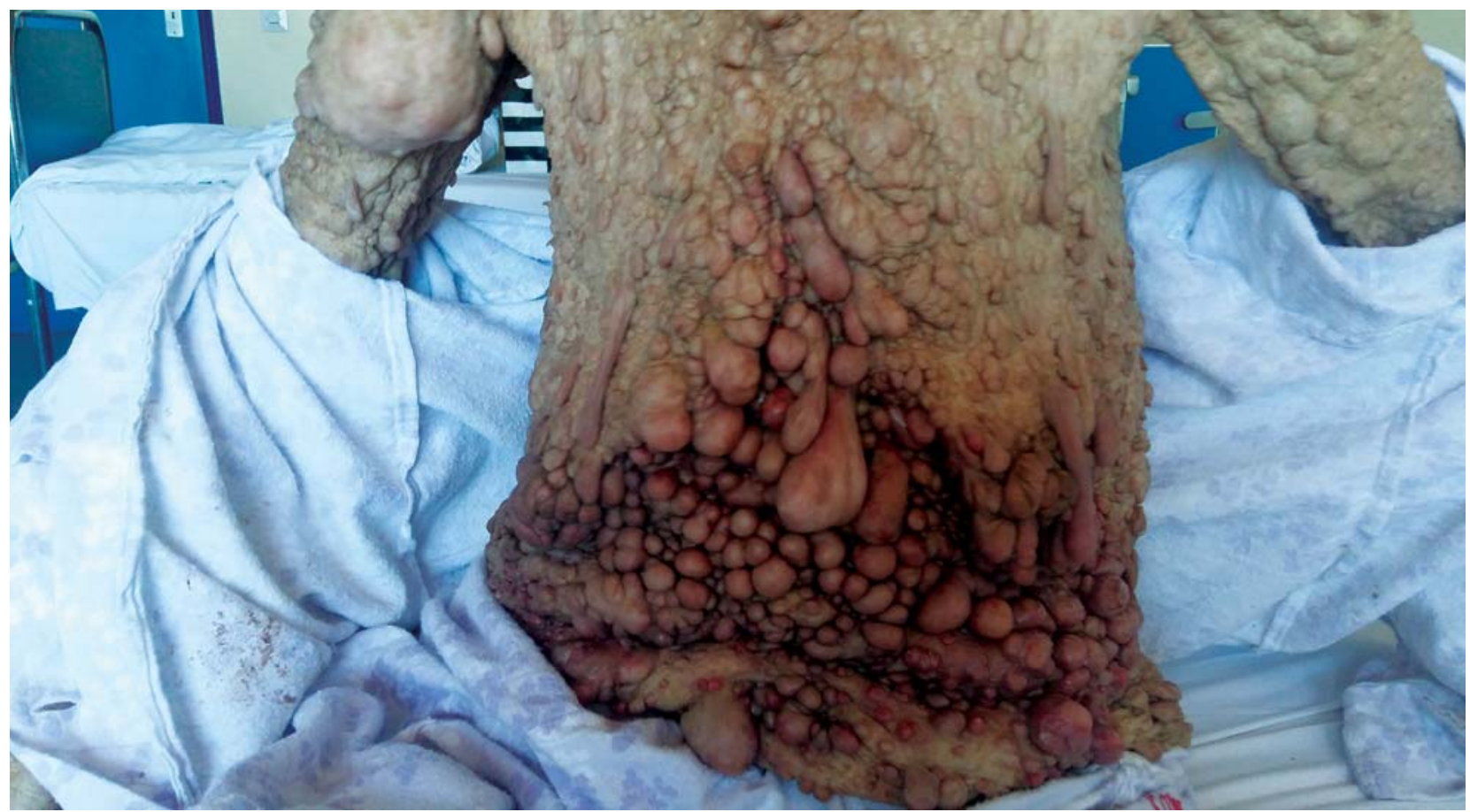

Figure 4. Inflamed neurofibromas in the abdominal area (erythematous, moist, some bleeding at the base) 


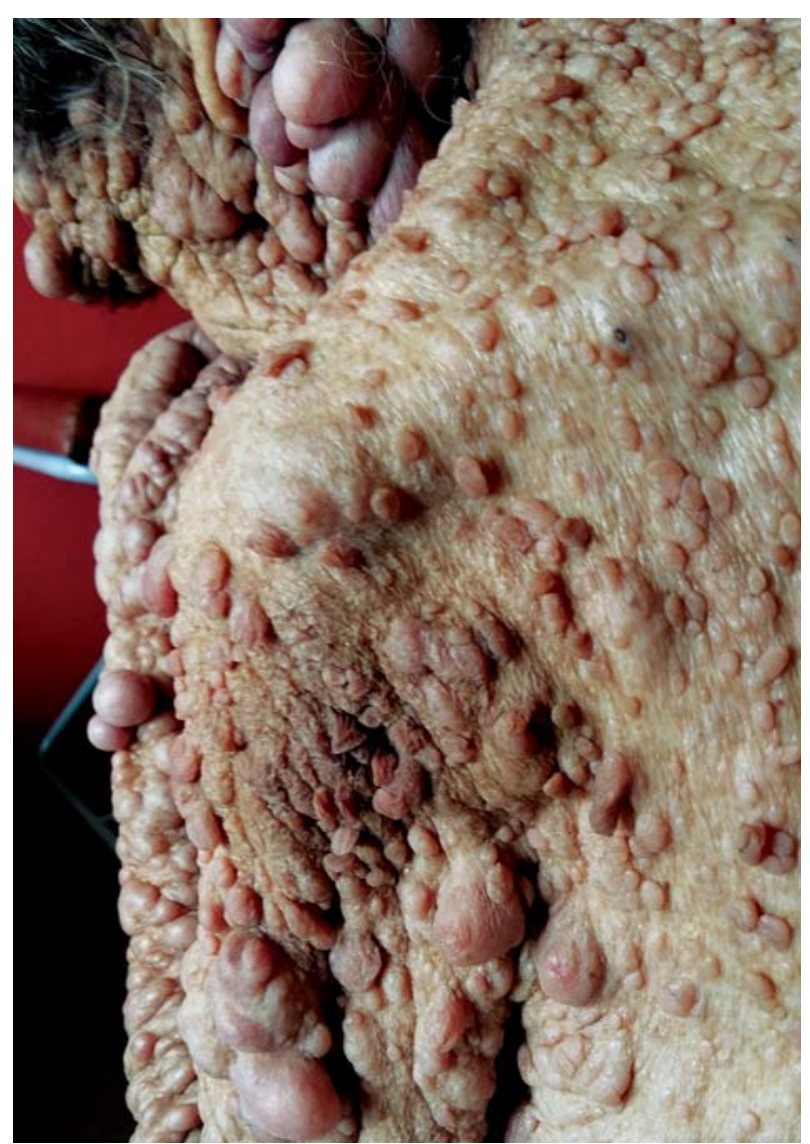

Figure 5. A small fibroma with comedone on the upper back
Native abdominal X-ray: normal findings.

$\mathrm{X}$-ray of the lower extremities and pelvis (standard views): bone structures showed no evidence of trauma or other pathological changes; normal joint width.

CT of the head: bone structures showed marked osteoporosis, as well as osteosclerotic lesions; flattening of the paraventricular gyri and reduction of brain parenchyma with hypodensity of the white matter in terms of cortical atrophy; periventricular bilateral small post-ischemic microvascular brain lesions of varying chronicity.

Thoracic CT detected: in the lung parenchyma of the upper left lobe the apical presence of small area of pleural effusion with consequent subatelectatic zone; left hilum of involutile appearance with posterobasal, partly anterior, as well as laterobasal parts of atelectasis; no signs of axillary or mediastinal lymph nodes enlargement; coronary vessels without pathological changes, no pericardial effusions; bone structures showed no signs of infiltrative changes; arthropathic-spondylotic degenerative changes of the thoracic-lumbar spine segment with signs of diffuse skeletal hyperostosis.

CT of the abdomen revealed the following disorders: diffuse fatty liver infiltration; markedly distended stomach filled with heterogeneous contents; small inner stomach wall herniation, posterior and medially to the left; hypotrophic right kidney; atherosclerotic lesions of the abdominal aorta;

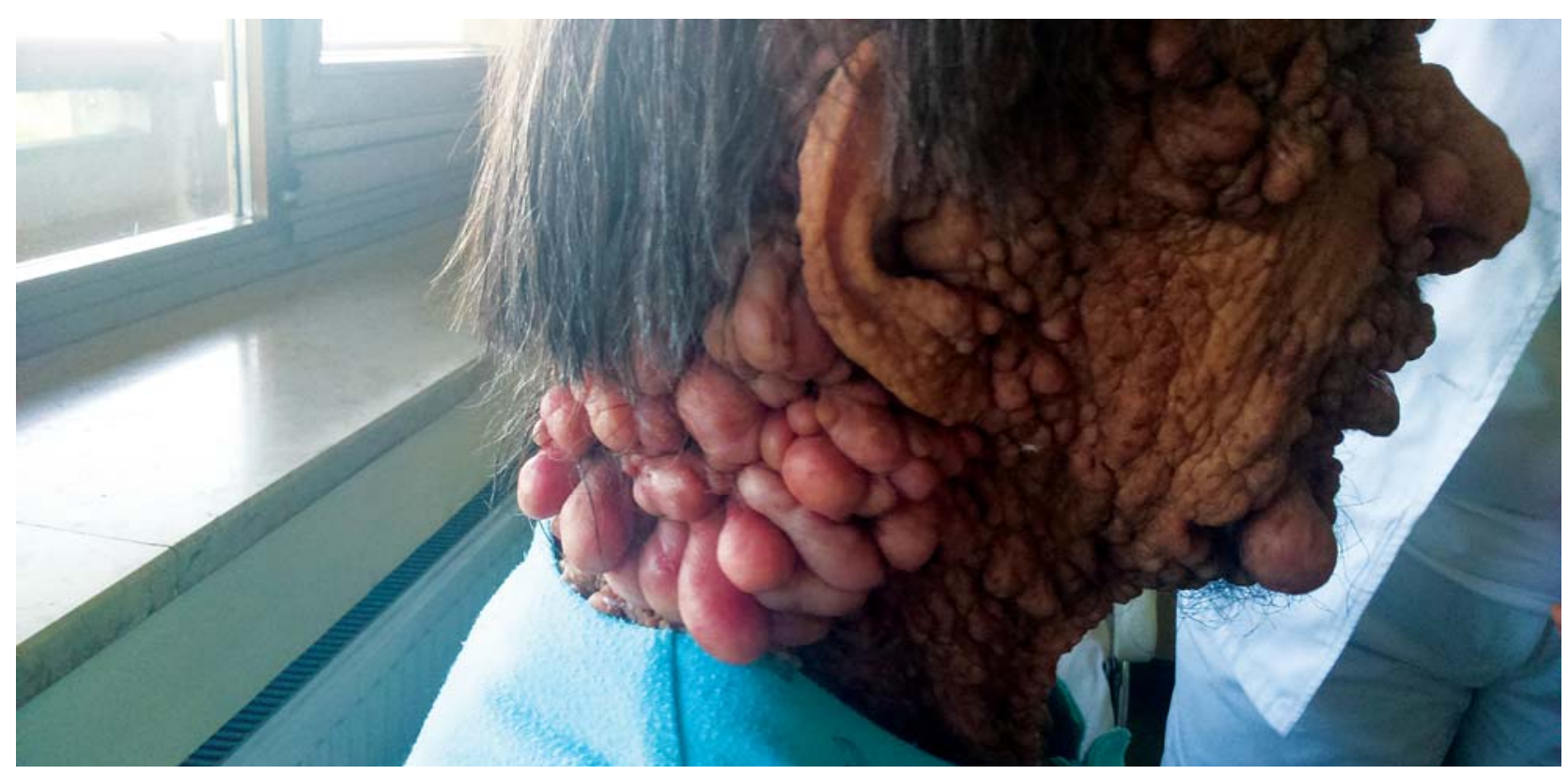

Figure 6. Clusters of neurofibromas on the occipital region and the neck 


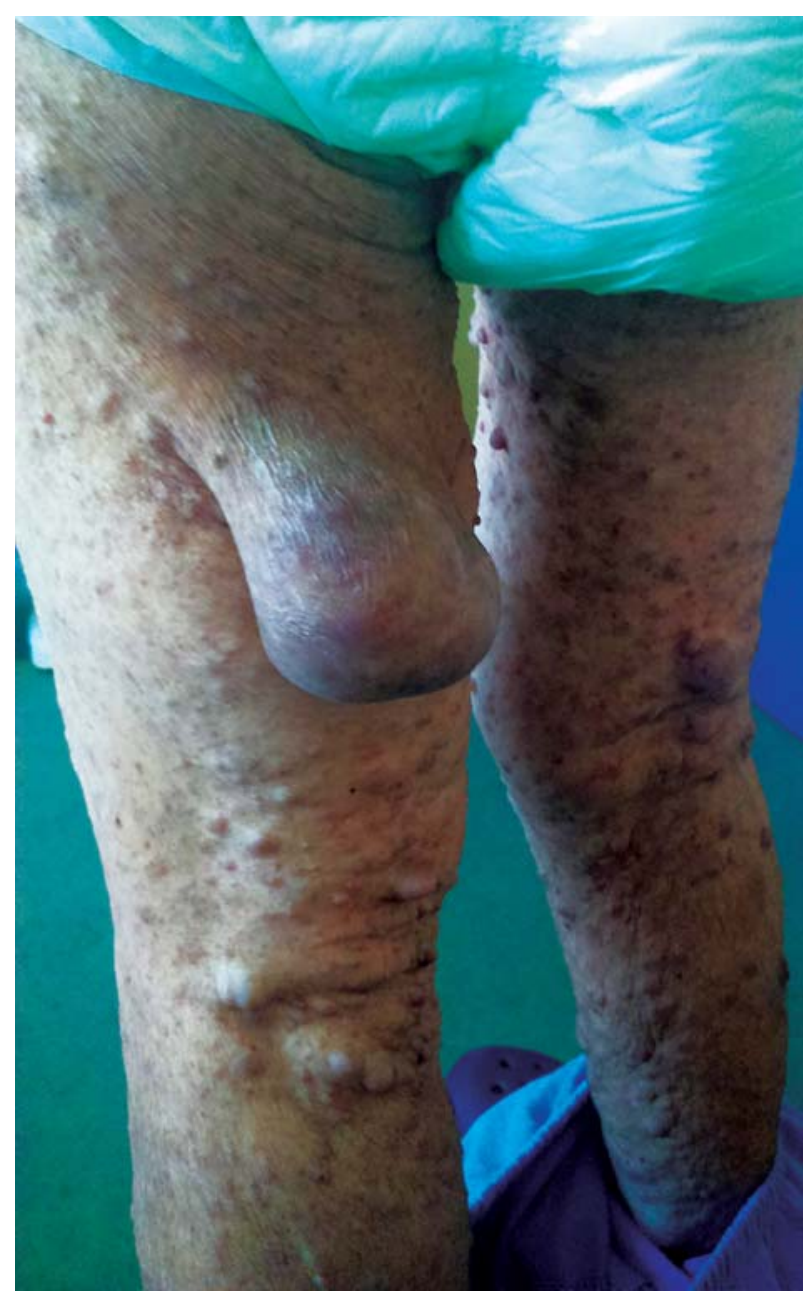

Figure 7. A giant, "bag-like" neurofibroma on the back of the left thigh

low grade infrarenal kinking of the abdominal aorta; pronounced degenerative changes in the lumbar spine.

Pathohistological analysis of biopsy specimens taken from the nodules corresponded to cutaneous neurofibroma (Figures 11 and 12).

Consultative examinations of various specialists pointed to the existence of the following comorbidities: obstructive respiratory syndrome and right lobe pneumonia that were treated by antibiotics, aminophylline and dexamethasone infusions; psychoorganic syndrome without focal neurological deficit; Lisch nodules in each eye, and senile cataract.

\section{Control laboratory tests}

After the patient was dismissed from the hospital, control laboratory tests showed abnormal test results

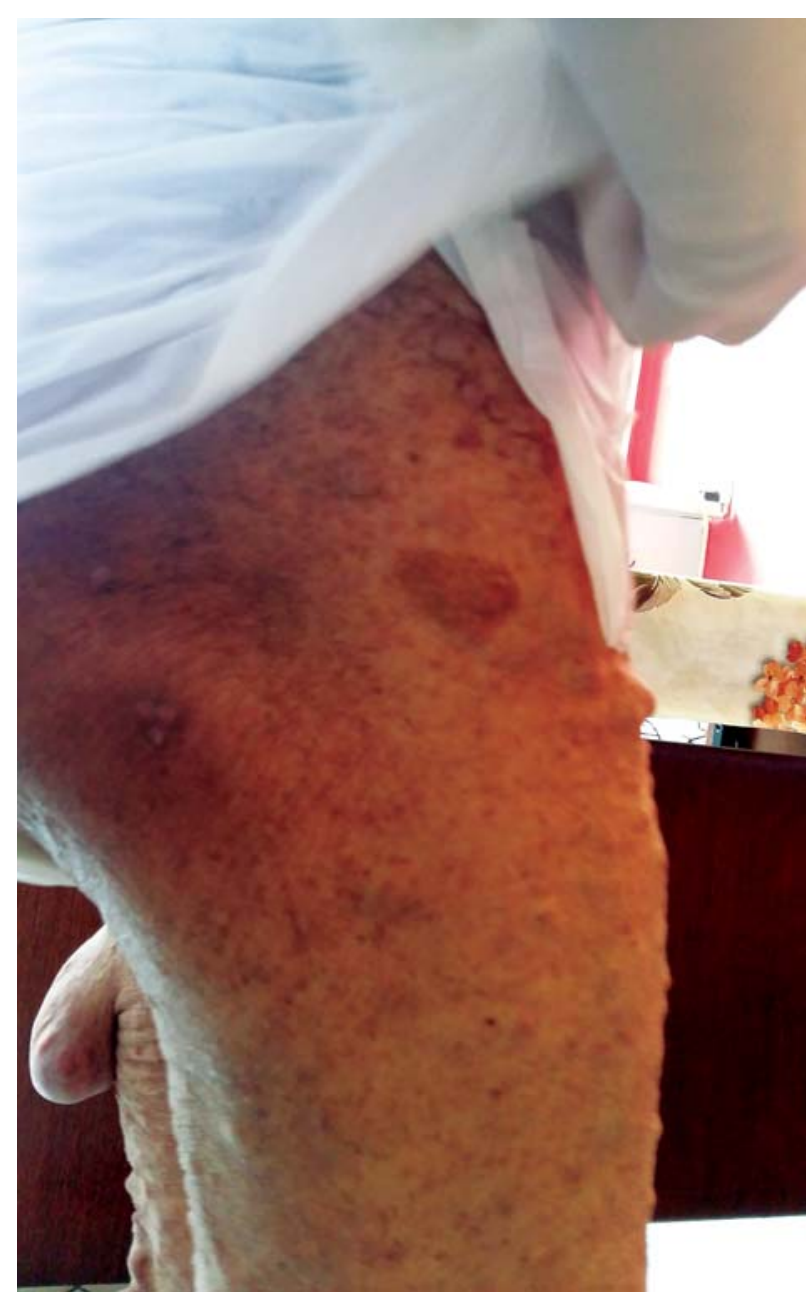

Figure 8. Café au lait macula on the right side of the body

as follows: C-reactive protein $36.7 \mathrm{mg} / \mathrm{L}$, hemoglobin $109 \mathrm{~g} / \mathrm{L}$, white blood cell count $10.22 \times 10^{9} / \mathrm{L}$, urea $8.1 \mathrm{mmol} / \mathrm{L}$, creatinine $113 \mu \mathrm{mol} / \mathrm{L}$; urinalysis $1+$ protein.

\section{Therapy}

During the hospital stay, the patient received oral antibiotics (cephalexin capsules $2 \times 1 \mathrm{~g}$ /day for ten days, followed by azithromycin 1 x $250 \mathrm{mg}$ tablets/day for five days), and dexamethasone and aminophylline infusions in $0.9 \% \mathrm{NaCl}$ solution, plus oral ranitidine. Inflamed neurofibromas were topically treated by aqueous solution of eosin $2 \%$. She was discharged in good general condition, the inflammation of neurofibromas was managed and she showed no distinct respiratory symptoms. 


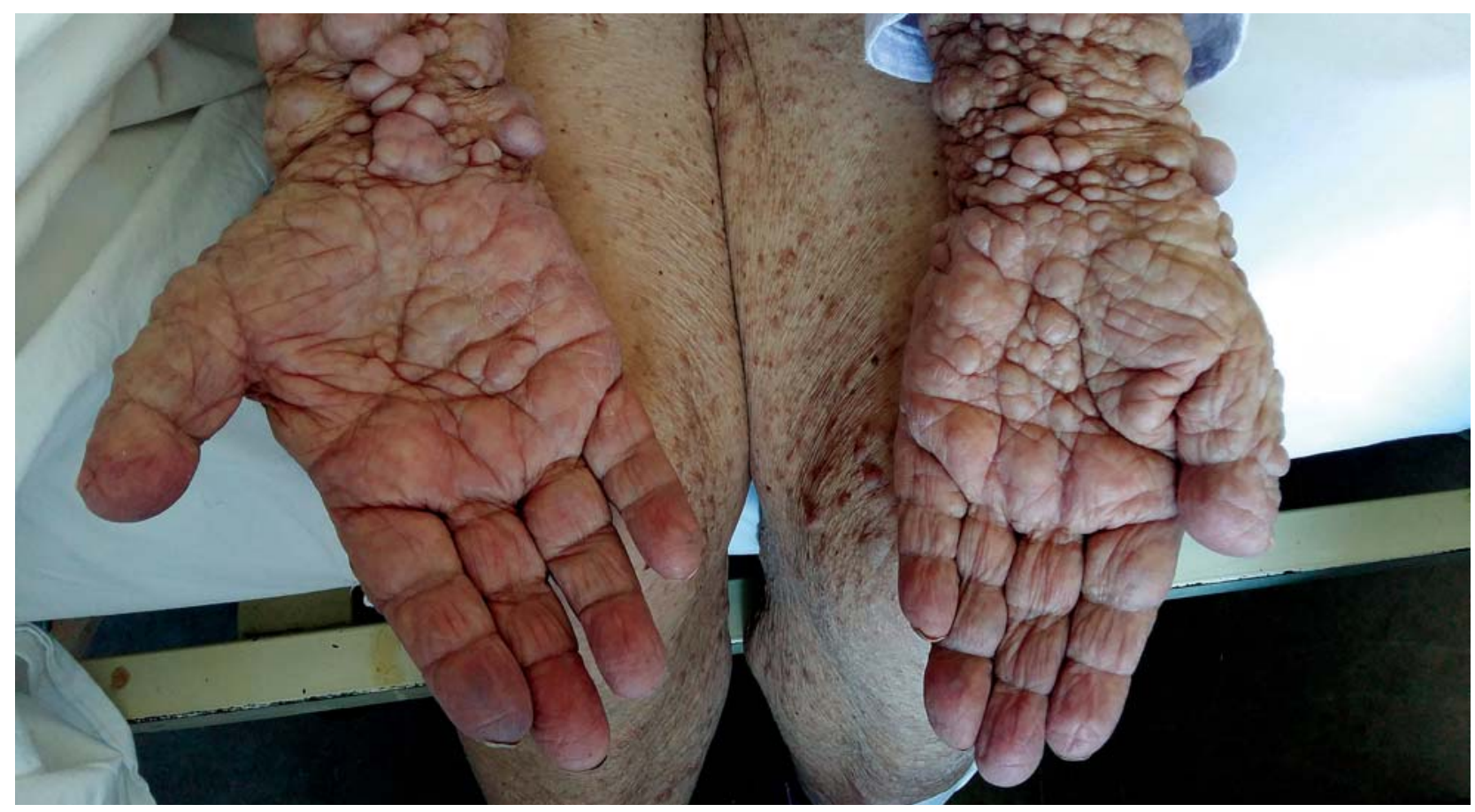

Figure 9. Neurofibromas on the distal parts of forearms and hands with small brownish hyperpigmented spots, involving the groin region and the proximal part of thighs

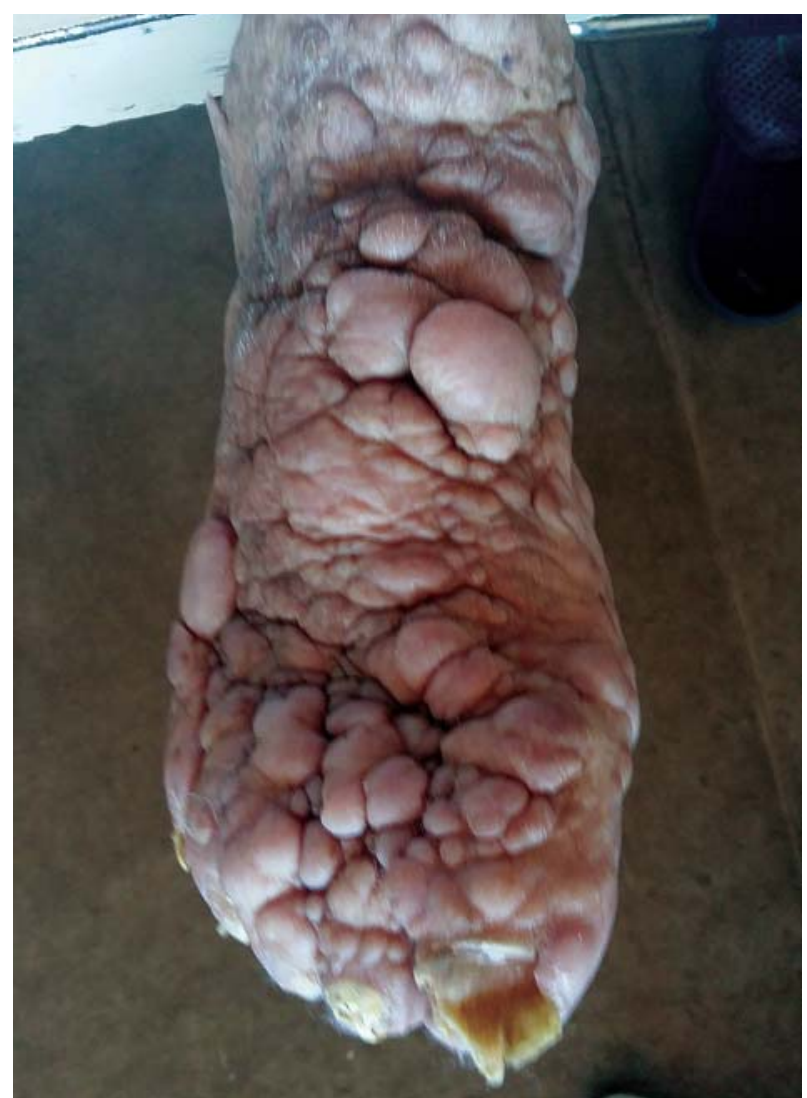

Figure 10. Neurofibromas on the dorsal aspect of feet

\section{Discussion}

The large NF1 gene is located on chromosome 17q11.2. This gene comprises 60 exons and spans $350 \mathrm{~kb}$ of genomic DNA. The protein product of this gene, neurofibromin, consists of 2,818 amino acids and is present in various tissues, mostly in nervous tissue $(6,9)$. Mast cells increase in neurofibromas and may enhance growth of these tumors by producing several growth factors, such as histamine and tumor necrosis factor (TNF) (1). The neurofibromin protein shows significant regions of similarity to the guanosine triphosphatese (GTPase)-activating protein and is capable of down-regulation of Ras activity. NF1 germline mutations cause haploinsufficiency of neurofibromin, which is only $50 \%$ of the normal protein production by cells. Further investigations support the view that the NF1 gene acts as a suppressor of tumor activity, with a variety of somatic inactivating mutations identified in neurofibromas. The random acquisition of somatic mutation partly explains the delayed age of onset of the tumors associated with NF1 and variability of expression (1).

Neurofibromin deficiency affects cell types throughout the entire body, especially the neural crest cells that include Schwann cells, melanocytes, 


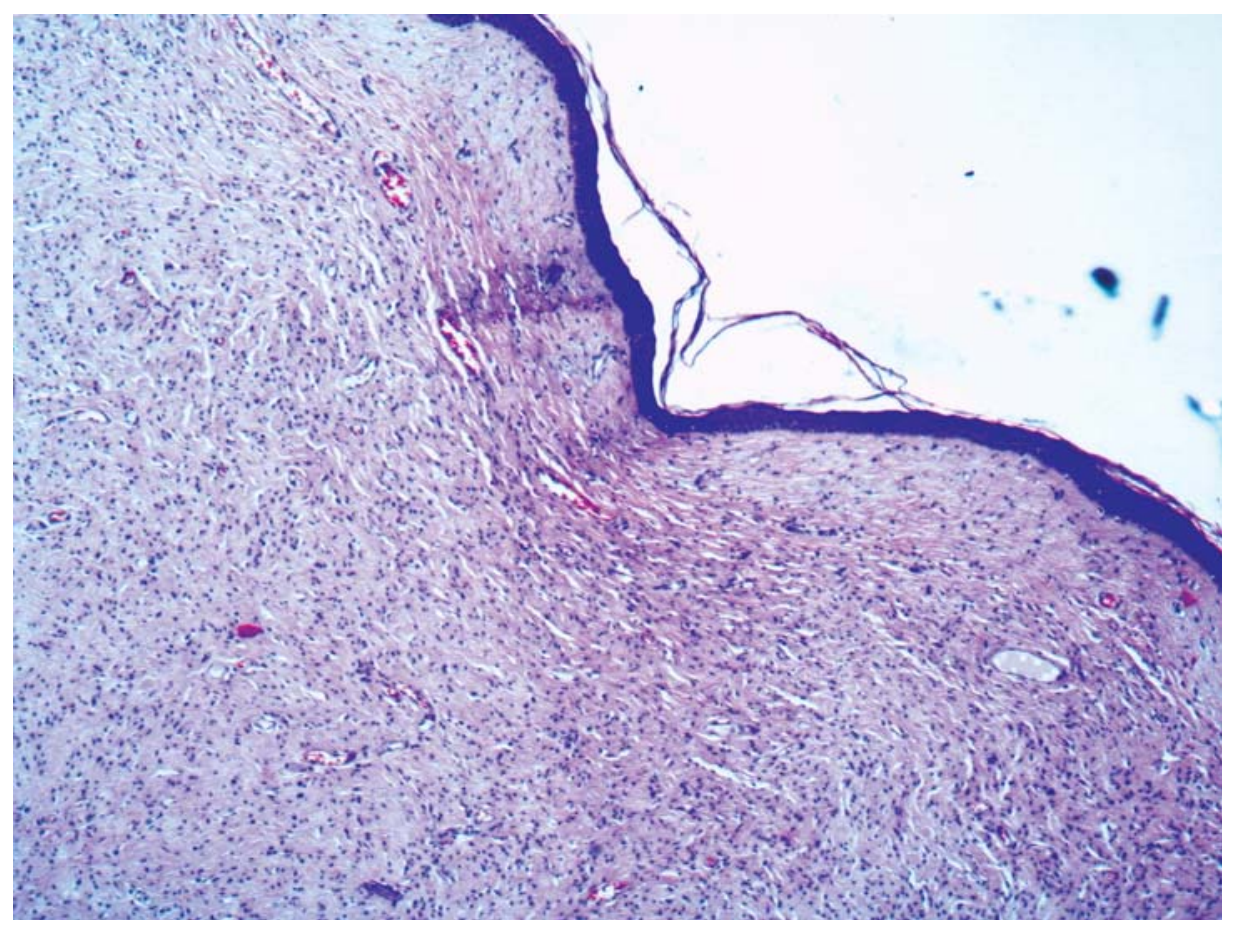

Figure 11. Pathohistological analysis of biopsy specimens taken from the nodule: the epidermis is thin, atrophic; cutaneous neurofibroma, vaguely defined from the surrounding dermis, infiltrated into the dermal connective tissue (HE stain, $x$ 50)

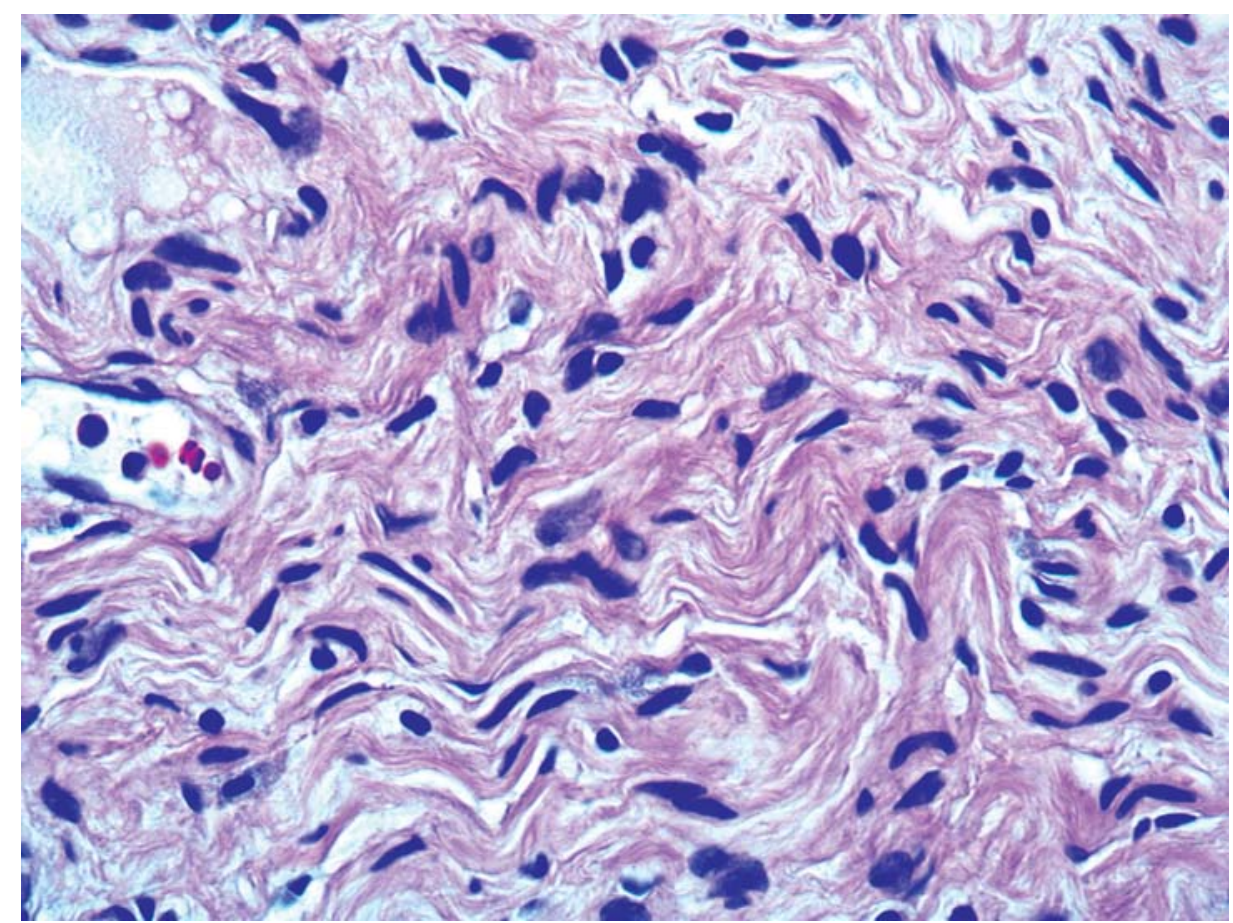

Figure 12. Higher manignification reveals: the tumor tissue comprises thin wavy fibers forming rare bundles; between uniform wavy fibers there are individual oval to spindle shaped nuclei, similar in size, located mainly in parallel rows; small amount of mature eosinophilic collagen is found between the aforementioned structures (HE stain, x 200) 
and endoneurial fibroblasts $(6,9)$. Consequently, the clinical manifestations of NF1 are extremely variable and unpredictable not only among individuals with this disease but with the same genotype.

The National Institutes of Health (NIH) Consensus Conference developed diagnostic criteria for NF1 that require at least two of the following clinical features, as outlined in Table $1(10,11)$.

The diagnosis is established based of clinical nearly pathognomonic (2). Generally, it occurs between the ages of 3 and 5 years, in either the axillae and/or groins. A majority of adults (about 90\%) have skinfold freckling. Other sites include neck folds, skin under the breasts, around the lips, and even the trunk in adults. Our patient presented with a great number of brown spots in the groin area and inner thighs. The size of freckles may vary from $1 \mathrm{~mm}$ to $3 \mathrm{~mm}$ (14).

Our patient presented with thousands of

Table 1. Diagnosticic criteria for NF1

\section{Criterion}

6 Café au lait macules, diameter: $>5 \mathrm{~mm}$ in prepubertal; $>15 \mathrm{~mm}$ in postpubertal patients

$\geq 2$ Cutaneous/subcutaneous neurofibromas or one plexiform neurofibroma

Freckling of armpits or groin

Optic pathway glioma

$\geq 2$ Lisch nodules (benign iris hamartomas)

Bone dysplasia (sphenoid wing dysplasia, long bone abnormalities - pseudoarthritis)

First-degree relative with NF 1

criteria. Molecular genetic testing is feasible. Identification of the NF1 gene means that prenatal/ presymptomatic diagnosis for this disease is now possible, with greater than $95 \%$ accuracy in families with affected members (1). The clinical manifestations of NF1 usually appear in a certain order as age increases: café au lait macules (CALMs), axillary freckling, Lisch nodules, and neurofibromas (9).

CALMs are frequently the first sign of NF1, occurring in $99 \%$ of NF1 patients within the first year of life $(1,3)$. Their color can range from skin color to dark brown. The prevalence of CALMs in the general population has varied from $3 \%$ to $36 \%$ depending on the study groups selected, but the presence of multiple macules in the general population typically is less than $1 \%$ (12). Patients continue to develop lesions throughout childhood, but they often fade in adulthood (13).

Skinfold freckling (Crowe's sign) is the most specific of the cardinal criteria for NF1. It is considered cutaneous neurofibromas which is the third hallmark signs of NF1. Neurofibromas usually do not become apparent until puberty and may continue to increase in size and number throughout adulthood. Neurofibromas can occur anywhere on the body and there is a wide variation in their shape and size. Generally, the "cutaneous" tumors are domeshaped, soft, fleshy as in our patient, their color varies from unchanged to slightly hyperpigmented. They may have the pathognomonic buttonholelike invagination when pressed with a finger. "Subcutaneous" tumors are firm and nodular. Pregnancy induces tumor growth $(9,14)$. The tumors are composed of Schwann cells, fibroblasts, mast cells, and perineural cells. There is also an admixture of collagen and extracellular matrix. There are several unusual, but well recognized variants of cutaneous neurofibromas that were not seen in our patient. The first are plexiform neurofibromas, 
uncommon variant of NF1 in which neurofibromas arise from multiple nerves as bulging and deforming masses involving also connective tissue and skin folds. Plexiform neurofibromas occur in up to $30 \%$ of cases with NF1, most frequently in the craniomaxillofacial region. These tumors are diffuse, growing along the length of a nerve and feel like a "bag of worms"; malignant progression is generally considered the main cause of mortality, occurring in $2-16 \%$ of cases (15). The second are blue-red and pseudoatrophic macules, unusual variants of cutaneous neurofibromas $(2,6)$. The increased serum levels of tumor markers were detected in our patient. Because of the extremely high number of tumors with different sizes, malignant alteration could not be excluded in the patient, although we did not detect plexiform neurofibromas.

Another common manifestation/symptom in NF1 is pruritus. Generally, it is a widespread cutaneous phenomenon, but anecdotally, some patients are able to distinguish certain tumors as more itchy than the others. The pathogenesis of this finding is uncertain, but may be related to the increased number of mast cells that are found in neurofibromas. However, if localized, pruritus can be a clue for the presence of an underlying spinal cord or central nervous tumor (16).

Our patient had all three cardinal skin manifestations: CALMs, groin freckling, and cutaneous neurofibromas. What makes this case rather peculiar is extremely high number of cutaneous neurofibromas of various sizes that covered almost the entire skin. Before being inflammed, neurofibromas in the abdominal region were very itchy causing severe scratching. On the rest of the skin, there were 4 typical and few faded CALMs. Due to the presence of fade CALMs, considering the patient's age, as well as the density and number of brownish neurofibromas, the pre-existence of CALMs in early age was indicative. Although early onset and rapid progression before puberty usually indicates a poor prognosis, minimal cutaneous involvement in the young child does not necessarily imply a favourable course. Extensive involvement of the urinary or gastrointestinal tract or the central nervous system carries a poor prognosis (1).

NF1 may affect almost every organ system, but the complaints vary between individuals, even within a single family. Extracutaneus findings of NF1 are numerous, and usually include skeletal, ophthalmologic, neurologic/psychologic, cardiovascular, endocrine, gastrointestinal, as well as malignant $(2,9)$ (Table 2$)$. In fact, the diagnosis of NF1 is often made in the middle age or later in life, as in our patient. The enormous variability of presentations appears to be at least partially genetically determined and is unrelated to the unaffected NF1 allele (1).

Bone abnormalities in NF1 are variable and include scoliosis, sphenoid wing or long bone dysplasia, but recently osteopenia/osteoporosis has been noted. The underlying pathogenic mechanisms are not fully understood, but experimental evidences suggest that NF1-deficient osteoblasts affect osteoclast differentiation leading to increased degradation of bone tissue. Scoliosis is the most common orthopedic finding in NF1, occurring in up to $10 \%$ of patients, being more apparent with aging and increases in puberty, suggesting a possible hormonal influence (1). The pathogenesis of this finding in NF1 is unknown, but it may be related to osteopenia and subsequent dysplastic bony elements. Dysplasia of long bones is another common manifestation of NF1, occurring in nearly $14 \%$ of patients, and it is usually evident within the first year of life. This finding is particularly relevant in dermatology, as young patients come to the Clinic for evaluation of "birthmarks" during the first year of life and can be easily screened for this manifestation. The tibia is the most commonly affected bone, bowing in an anterolateral direction. Coupled with the appropriate number and size of CALMs, this orthopedic manifestation is sufficient to make the diagnosis of NF1 at this age. Other findings may include overgrowth of a limb or congenital pseudoarthrosis (usually of the tibia), in which a fracture heals abnormally. Other skeletal abnormalities include short stature, relative macrocephaly, and a prominent forehead and brow. Nevertheless, 29 $45 \%$ of patients with NF1 have a head circumference greater than or equal to two standard deviations above the mean for sex and age $(17,18)$. Skeletal abnormalies detected in our patients were: short stature, head bone structures showed marked osteoporosis, as well as osteosclerotic lesions; degenerative spinal arthropathic spondylotic changes with signs of diffuse skeletal hyperostosis; pronounced degenerative changes in the lumbar spine. 
Table 2. Extracutaneus findings of neurofibrmatosis 1

\section{Finding}

Skeletal

\section{Symptom/Sign}

Scoliosis

Dysplasia of the long or sphenoid bones Macrocephally

Pectus excavatum

Prominent brow

Pseudoarthrosis (especially of the tibia)

Short stature

Optic glioma

Ophthalmologic

Neurologic/psychologic
Learning disabilities

Attention-deficit hyperactivity disorder

Seizures

Headaches

Epilepsy

\begin{tabular}{ll}
\hline Gastrointestinal & Constipation \\
& Gastrointestinal stromal tumors \\
\hline Endocrine & Pheochromocytoma \\
& Precocious puberty \\
& Hyposalivation \\
\hline Cardiovascular & Hypertension \\
& Vascular dysplasia \\
\hline Malignant & Juvenile myelomonocytic leukemia \\
& Malignant peripheral nerve sheath tumor \\
\hline
\end{tabular}

The presence of two or more Lisch nodules is another cardinal NF1 diagnostic criterion that was also present in our patient. These nodules are small, dome-shaped hyperpigmented macules of the iris that usually do not cause vision impairment. They are commonly seen: in about $15-20 \%$ of patients by the age of six years and in $95 \%$ of adults $(2,5)$. The optic nerve glioma, usually present in $15-20 \%$ of patients with NF1, but not in our case, is another diagnostic NF1 criterion. It is a slow-growing tumor and can present clinically as: proptosis, decreased visual acuity, or precocious puberty (the latter most commonly after the age of six) with accelerated linear growth as the evidence of early puberty, thus necessitating the use of growth charts in NF1 patients. Symptomatic optic gliomas are typically present prior to the age of six, with most children being diagnosed by the age of three (19). Ophtalmological abnormalities in our patient included lots of Lisch nodules and corticonuclear senile cataract of both eyes.

Cognitive dysfunctions, including significant learning difficulties, behavioral problems, and attention deficits, are the most common neurological problems associated with NF1. The prevalence of 
these cognitive deficits, also present in our patient, approaches $70 \%(8,20)$. Macrocephaly is another common feature of children with NF1. Macrocephalic subjects show significant increase in volume of the white matter, while increase of the grey matter of the brain has not achieved statistical significance (21). In contrast, our 78-year-old patient presented with flattening of the paraventricular gyri and reduction of brain parenchyma with hypodensity of the white matter in terms of cortical atrophy; periventricular bilateral small post-ischemic microvascular lesions of varying chronicity. Other, uncommon but wellknown neurological complications include headaches, sleep disorders, epilepsy, cerebral edema, mental retardation and tumors of the spinal cord and brain $(22,23)$. As our patient had learning difficulties in early childhood, due to which she did not finish elementary school similarly to her brothers and sisters, it can be concluded that she had cognitive disabilities as a neurological manifestation of NF1. In addition, the patient declared frequent headaches in the past two to three decades, the reason why she has been taking analgesics all the time.

Gastrointestinal manifestations of NF-1 are generally unrecognized by both clinicians and pathologists. The frequency of intra-abdominal (gastrointestinal or retroperitoneal) manifestations of NF-1 varies greatly in studies, ranging from 5 $25 \%$. Gastrointestinal manifestations usually arise during midlife or later; generally later than cutaneous manifestations. Compared to the cutaneous manifestations, neurogenic tumors are relatively uncommon in the gastrointestinal tract. They may occur at any site from the esophagus to anorectum and in the associated peritoneal and mesenteric soft tissues $(24,25)$. Our patient complained of occasional abdominal pain, whereas CT of the abdomen showed distended stomach and a small inner wall herniation.

The American Academy of Pediatrics has published diagnostic and health supervision guidelines for children with NF1, which include measurement of blood pressure, as well as assessing children for precocious puberty by annual evaluation of growth and sexual development (26). NF1 patients have a lifetime risk of $1-5 \%$ for the development of a pheochromocytoma with sustained hypertension in approximately $60 \%$ of all cases. These tumors are almost exclusively localized on a single or both adrenal glands. Rarely they are malignant and in most patients can be treated by surgery (27). Inherited pancreatic endocrine tumors, especially duodenal carcinoids (somatostatinomas) can occur as a part of NF-1, with a penetrance of approximately $1 \%$ (28). In a recent case-control study, hyposalivation was estimated in $59 \%$ of 49 individuals with neurofibromatosis 1. Authors suggested that hyposalivation may be a consequence of NF1, but more studies are needed to prove this hypothesis (29). No such abnormalities have been detected in our patient.

Patients with NF1 are at increased risk for a variety of cardiovascular disorders (30). Cardiovascular complications include hypertension, vasculopathy, cardiomyopathy, heart defects and superior vena cava obstruction. Mediastinal neurofibromas have been well documented as causes of superior vena cava compression. Congenital lesions have potential long-term hemodynamic consequences that justify an early diagnosis $(9,31)$. During hospitalization the patient's blood pressure and electrocardiogram were normal. CT scans revealed a hypotrophic right kidney; atherosclerotic lesions of the abdominal aorta; low grade infrarenal kiking of the abdominal aorta.

A study on NF1 associated mortality included 1895 patients in France; the mortality rate was significantly increased, and malignant nerve sheath tumors were the main cause of death in about $60 \%$ of all cases (32). Cutaneous neurofibromas are invariably benign but subcutaneous and plexiform neurofibromas may undergo malignant transformation in about 8 $13 \%$ of patients with NF1 (33). High grade lesions herald a poor prognosis. The clinical symptoms include pain, rapid growth, changes in texture and neurological deficit $(34,35)$. Long-term follow-up has shown reduced life expectancy related to the development of malignancy and other tumors that may occur such as gastrointestinal stromal tumors, gastric carcinoid, juvenile myelomonocytic leukemia, glomus tumors, astrocytomas and pheochromocytomas $(1,7)$.

Currently, there are no effective treatment modalities specific for NF1. The treatment is symptomatic. Some disfiguring lesions can be excised if not too diffuse. Painful and bleeding tumors and cosmetic enhancement warrant surgical intervention, including various surgical techniques and lasers. The 
advent of new treatment options for NF1 such as topical vitamin D3 analogues, lovastatin, rapamycin (or sirolimus), and imatinib mesylate have added new dimensions that require further investigations to prove their therapeutic efficacy.

We used antibiotic therapy for pneumonia and secondary skin infection in our patient. Considering the age and medical presentation, we did not consider any other treatment.

Genetic counselling is important. It should be made clear to patients that $50 \%$ of their children are likely to be affected and that the disease may be severe. First-degree relatives (e.g. siblings and offsprings) who have no stigmata of the disease are unlikely to carry the gene and the risk for their offsprings is small but not absent, as gonadal mosaicism has been observed. Prenatal diagnosis is also not an option for approximately $50 \%$ of cases who will present with new mutations (1).

\section{Conclusion}

This is a sporadic case of cutaneous neurofibromatosis 1 in a 78-year-old female patient who exhibited extremely severe clinical aspects of cutaneous neurofibromas, making this case at least rather peculiar.

\section{Abbreviations}

NFs - neufibromatoses

NF1 - neurofibromatosis 1

NIH - National Institutes of Health

CALMs - "caffe au lait macules"

$\mathrm{Kb}$ - kilobase

GTPase - guanosine triphosphatase

TNF- tumor necrosis factor

RTG - X-ray

CT - computed tomography

\section{References}

1. Irvine AD, Mellerio JE. Genetics and genodermatoses. In: Burns T, Breathnach S, Cox N, Griffiths C, editors. Rook's textbook of dermatology. $8^{\text {th }}$ ed. Oxford: Blackwell Publishing Ltd; 2010. p. 15.1-15.97.

2. Sehgal VN, Verma P, Chatterjee K. Type 1 neurofibromatosis (von Recklinghausen disease). Cutis 2015;96(3):E23-6.

3. von Recklinghausen F. Uber die Multiplen Fibrome der Haut und Ihre Beziehung $\mathrm{Zu}$ Den Multiplen Neuromen. Berlin: August Hirschwald; 1882.
4. Crowe FW, Schull WJ, Neel JV. A clinical, pathological and genetic study of multiple neurofibromatosis. Springfield, IL: Charles C Thomas; 1956.

5. Boyd KP, Korf BR, Theos A. Neurofibromatosis type 1. J Am Acad Dermatol 2009;1(1):1-16.

6. Jouhilahti EM, Peltonen S, Heape AM, Peltonen J. The pathoetiology of neurofibromatosis 1. Am J Pathol 2011;178(5):1932-9.

7. Laycock-van Spyk S, Thomas N, Cooper DN, Upadhyaya M. Neurofibromatosis type 1-associated tumours: their somatic mutational spectrum and pathogenesis. Hum Genomics 2011;5(6):623-90.

8. Diggs-Andrews KA, Gutmann DH. Modeling cognitive dysfunction in neurofibromatosis-1. Trends Neurosci 2013;36(4):23747.

9. Fox CJ, Tomajian S, Kaye AJ, Russo S, Abadie JV, Kaye AD. Perioperative management of neurofibromatosis type 1 . Ochsner J 2012;12(2):111-21.

10. Ferner RE, Huson SM, Thomas N, Moss C, Willshaw H, Evans DG, et al. Guidelines for the diagnosis and management of individuals with neurofibromatosis 1. J Med Genet 2007;44(2):81-8.

11. Gabriele AL, Ruggieri M, Patitucci A, Magariello A, Conforti FL, Mazzei R, et al. A novel NF1 gene mutation in an Italian family with neurofibromatosis type 1. Childs Nerv Syst 2011;27(4):635-8

12. Allouche J, Bellon N, Saidani M, Stanchina-Chatrousse L, Masson Y, Patwardhan A, et al. In vitro modeling of hyperpigmentation associated to neurofibromatosis type 1 using melanocytes derived from human embryonic stem cells. Proc Natl Acad Sci USA 2015;112(29):9034-9.

13. Shah KN. The diagnostic and clinical significance of café-aulait macules. Pediatr Clin North Am 2010;57(5):1131-53.

14. Tchernev G, Chokoeva AA, Patterson JW, Bakardzhiev I, Wollina U, Tana C. Plexiform neurofibroma- a case report. Medicine (Baltimore) 2016;95(6):e2663.

15. Staser K, Yang FC, Clapp DW. Pathogenesis of plexiform neurofibroma: tumor-stromal/hematopoietic interactions in tumor progression. Annu Rev Pathol 2012;7:469-95.

16. O'Brien DE, Brenner DS, Gutmann DH, Gereau RW. Assessment of pain and itch behavior in a mouse model of neurofibromatosis type 1. J Pain 2013;14(6):628-37.

17. Korf BR. Statins, bone, and neurofibromatosis type 1. BMC Med 2008;6:22

18. Arun KP, Joseph T, Jaishankar HP, Abhinethra MS. Von Recklinghausens disease: a series of four cases with variable expression. J Maxillofac Oral Surg 2015;14(1):161-7.

19. Rodriguez FJ, Perry A, Gutmann DH, O’Neill BP, Leonard J, Bryant $S$, et al. Gliomas in neurofibromatosis type 1: a clinicopathologic study of 100 patients. J Neuropathol Exp Neurol 2008;67(3):240-9.

20. Klein-Tasman BP, Janke KM, Luo WL, Casnar CL, Hunter SJ, Tonsgard JT, et al. Cognitive and psychosocial phenotype of young children with neurofibromatosis-1. J Int Neuropsychol Soc 2014;20(1):88-98.

21. Gutmann DH, Parada LF, Silva Aj, Ratner N. Neurofibromatosis type 1: modeling CNS dysfunction. J Neurosci 2012;32(41):14087-93.

22. Madubata CC, Olsen MA, Stwalley DL, Gutmann DH, 
Johnson KJ. Neurofibromatosis type 1 and chronic neurological conditions in the United States: an administrative claims analysis. Genet Med 2015;17(1):36-42.

23. Licis AK, Vallorani A, Gao F, Chen C, Lenox J, Yamada KA, et al. Prevalence of sleep disturbances in children with neurofibromatosis type 1. J Child Neurol 2013;28(11):1400-5.

24. Agaimy A, Vassos N, Croner RS. Gastrointestinal and retroperitoneal manifestations of neurofibromatosis type 1 (Recklinghausen's disease): clinicopathological spectrum with pathogenetic considerations. Int J Clin Exp Pathol 2012;5(9):852-62.

25. Salvi P, Lorenzon L, Caterino S, Antolino L, Antonelli MS, Balducci G. Gastrointestinal stromal tumors associated with neurofibromatosis 1: a single centre experience and systematic review of the literature including 252 cases. Int J Surg Oncol 2013;2013:398570.

26. Hersh JH. Health supervision for children with neurofibromatosis. Pediatrics 2008;121(3):633-42

27. Zografos GN, Vasiliadis GK, Zagouri F, Aggeli C, Korkolis D, Vogiaki S, et al. Pheochromocytoma associated with neurofibromatosis type 1: concepts and current trends. World J Surg Oncol 2010;8:14.

28. Lodish MB, Stratakis CA. Endocrine tumours in neurofibromatosis type 1 , tuberous sclerosis and related syndromes. Best Pract Res Clin Endocrinol Metab 2010;24(3):439-49.

29. Cunha KS, Rozza-de-Menezes RE, Luna EB, Almeida LM,
Pontes RR, Almeida PN, et al. High prevalence of hyposalivation in individuals with neurofibromatosis 1: a case-control study. Orphanet J Rare Dis 2015;10:24.

30. Friedman JM, Arbiser J, Epstein JA, Gutmann DH, Huot SJ, Lin AE, et al. Cardiovascular disease in neurofibromatosis 1: report of the NF1 Cardiovascular Task Force. Genet Med 2002;4(3):105-11.

31. Oderich GS, Sullivan TM, Bower TC, Gloviczki P, Miller DV, Babovic-Vuksanovic D, et al. Vascular abnormalities in patients with neurofibromatosis syndrome type I: clinical spectrum, management, and results. J Vasc Surg 2007;46(3):475-84.

32. Duong TA, Sbidian E, Valeyrie-Allanore L, Vialette C, Ferkal S, Hadj-Rabia S, et al. Mortality associated with neurofibromatosis 1: a cohort study of 1895 patients in 1980-2006 in France. Orphanet J Rare Dis 2011;6:18.

33. Park SJ, Sawitzki B, Kluwe L, Mautner V, Holtkamp N, Kurtz A. Serum biomarkers for neurofibromatosis type 1 and early detection of malignant peripheral nerve-sheath tumors. BMC Med 2013;11:109.

34. Karajannis MA, Ferner RE. Neurofibromatosis-related tumors: emerging biology and therapies. Curr Opin Pediatr 2015;27(1):2633.

35. Walker L, Thompson D, Easton D, Ponder B, Ponder M, Frayling I, et al. A prospective study of neurofibromatosis type 1 cancer incidence in the UK. Br J Cancer 2006;95(2):233-8.

\section{Ekstremno izražena kutana neurofibromatoza tip i posledica nove mutacije - prikaz slučaja}

\section{Sažetak}

Uvod. Neurofibromatoza tip 1 predstavlja jedno među najčešćim naslednim multitistemskim oboljenjima. Manifestuje se nekolikim karakterističnim promenama koje imaju dijagnostički značaj: većim brojem makula boje bele kafe (fr. café-au-lait macules), hiperpigmentacijama u pazušnim jamama, Lišovim čvorićima na šarenici (dužica) oka i neurofibromima (benigni tumori poreklom iz ovojnice perifernih nerava). Udružene ekstrakutane kliničke manifestacije bolesti podrazumevaju najčešće prisustvo skeletnih abnormalnosti, neuroloških, kardiovaskularnih, endokrinih ili malformacija drugih organa i sistema. Neurofibromatoza tip 1 nastaje kao posledica mutacije na NF-1 genu koji kodira sintezu neurofibromin proteina. Bolest se nasleđuje autozomno-dominanto, ali kod 50\% obolelih oboljenje nastaje kao posledica novonastale (de novo) mutacije, tako da osoba predstavlja prvog obolelog u porodici. Nisu utvrđene razlike u kliničkoj slici ili težini oboljenja između onih koji su nasledili oboljenje i onih koji predstavljaju prve obolele u porodici.

Prikaz slučaja. U radu je prikazana 78-godišnja ženska osoba sa ekstremno izraženim kutanim manifestacijama oboljenja i koja je predstavljala prvi slučaj bolesti u porodici. U detinjstvu i mladosti, osim kožnih, nije imala značajnijih problema sa zdravljem, ali poslednjih decenija je imala češće glavobolje, povremene bolove u stomaku, slabiji vid i sluh. Desetak do četrnaest dana pre prijema u bolnicu počela je jače da kašlje, da otežano diše, i da oseća bolove u grudima i stomaku. Na pregledu, izuzev na koži ekstenzornih strana natkolenica i potkolenica, koža celog tela pacijentkinje niskog rasta $(152 \mathrm{~cm})$, telesne mase 49 $\mathrm{kg}$ bila je prekrivena hiljadama gusto raspoređenih mekih kutanih nodusa; boja nodusa varirala je od boje kože, lividnoerimatozne do sivkastosmeđe; nodusi u predelu abdomena su bili vlažni, mestimično su pri bazi krvarili i bili praćeni neprijatnim mirisom. $\mathrm{Na}$ 
stopalima su takođe bile prisutne gusto raspoređene čvoraste, tumorozne promene uz distrofične promene na noktima koji su bili zadebljali, iskrzani, žućkastog kolorita. Skeletne malformacije prisutne kod naše pacijentkinje bile su: nizak rast, izražena osteoporoza i zona osteosklerotskog karaktera na koštanim strukturama glave; degenerativne artropatskospondilotske promene torakolumbalnog segmenta kičme sa znacima difuzne skeletne hiperostoze; izrazito degenerativne promene lumbalne kičme.

Pregledom glave (CT), grudnog koša i abdomena utvrđene su sledeće abnormalnosti: aplatacije girusa paraventrikularno i redukcija moždanog parenhima sa hipodenzitetom bele mase u smislu znakova kortikalne atrofije; periventrikularno obostrano, manje mikro-vaskularne cerebralne postishemijske lezije različitog hroniciteta; u plućnom parenhimu gornjeg levog plućnog režnja apikalno, kao i apikoposteriorno odnosno anteriorno, prisustvo manje zone pleuralne efuzije sa subatelektatičnom zonom kao posledicom; distendiran želudac i manja unutrašnja hernija zida želuca; hipotrofičan desni bubreg; aterosklerozne promene abdominalne aorte; niskostepeno uvrtanje (engl. kinking) infrarenalnog segmenta abdominalne aorte. Patohistološka analiza bioptiranog nodusa je po opisu odgovarala kutanom neurofibromu. Konsultativni pregledi lekara razičitih specijalnosti ukazali su na postojanje sledećih komorbiditeta: opstruktivni respiratorni sindrom i levostrana upala pluća i zbog toga je ordinirana antibiotska terapija, aminofilin i deksametazon u infuziji; psihoorganski sindrom bez fokalnog neurološkog deficita; Lišovi noduli na irisu oba oka; senilna katarakta. Uzimajući u obzir starost i klinički status pacijentkinje, sprovedena je antibiotska i relevantna internistička simptomatska terapija.

Zaključak. U radu je prikazan sporadičan slučaj kutane neurofibromatoze 1 kod 78-godišnje ženske osobe sa preko hiljadu ekstremno izraženih neurofibroma.

Ključne reči: Neurofibromatoza 1; Neurofibrin 1; Café-au-Lait fleke; Bolesti dužice; Melanoza; Neurofibrom; Kožne neoplazme; Prikazi slučajeva; Komorbiditet 